\title{
Research on Applications of the Communicative Principle in Russian Teaching
}

\author{
Chen Binbin \\ Zunyi Normal College, Zunyi, Guizhou, China, 563002 \\ hunter2011@foxmail.com
}

Keywords: Communicative principle, Russian teaching, Applications.

\begin{abstract}
The communicative principle is the principle of learning a foreign language through a large number of language dialogues. As the principle of communication attaches much importance to the use of the foreign language, it effectively helps the language learner. This paper analyzes the application of the communicative principle in Russian language teaching, including its application in dialogue teaching, grammar teaching, vocabulary teaching and text teaching in order to provide some references for the college Russian teachers.
\end{abstract}

\section{Concept of the Communicative Principle}

The communicative principle is to learn the dialogue, grammar, vocabulary and texts of the foreign language through much dialogue practice. Communicative teaching is formed in the late 70 's and early 80's, and its theory mainly comes from the social linguistics, Chomsky's transformational generative method, as well as the psychological linguistics. It advocates teaching students how to use the language in the first place. However, in the actual teaching process, the implementation of the principle of communication is not very smooth. We learn foreign languages, mainly in order to communicate with foreign language. In Russian teaching, the teacher should pay attention to strengthen the basic knowledge of students, enhance their listening, speaking, reading, writing and other basic functions, to develop students in the oral and written proficiency in the use of Russian language ability, rather than the ability to test. The main function of language is to communicate feelings, ideas and information, so the teaching of foreign language should not be the core of the grammar as an absolute. Teachers in the classroom can be simulated by the scene to practice. It can be equipped with a number of multimedia teaching methods to create a vivid image of the students' communication atmosphere. Communicative approach is a comprehensive teaching method which combines the traditional teaching method and the reinforcement method, but it also has a series of characteristics of itself. This teaching method can help people overcome language conflicts and help people get rid of the fear of another language. In summary, the communicative principle is one of teaching foreign language methods through communication.

\section{Advantages and Disadvantages of the Communicative Principle}

Advantages. Communication is not only the purpose of foreign language teaching, but also the means of foreign language teaching. The communicative approach is closely integrated, "learning" and "using" high degree of unity, foreign language learners in the learning of new knowledge can be immediately applied to the actual communication, so that foreign language learners can be able to grasp the initial foreign language communicative competence in a short period of time, the effect of vertical pole. To the students as the center, the communicative approach to break the previous teaching method has been advocated by the "teachers in the teaching activities in the main position", the students as the main body and center of teaching activities, students are "actors", and teachers are the organizers of teaching activities, is the director". The communicative approach emphasizes on the active exploration of knowledge in the whole foreign language teaching activity, which is based on the experience, which is not emphasized by the teaching method. This is not the emphasis of the teaching method, which is beneficial to the students' ability of independent learning, independent thinking and innovation, so as to achieve the ultimate goal of foreign language teaching. Communication method is a change in the past the traditional foreign language teaching 
mode, the teacher is no longer blindly plugging to students' grammar and vocabulary knowledge without considering the student is interested in teaching contents, which leads directly to the teacher taught a lot, and the students can really master the rarely. Communicative approach emphasizes students' future career need what, what the teacher taught, give full consideration to the students' interest in learning, to meet the learning needs of students, more conducive to stimulate students' interest in learning. At the same time, it creates more opportunities for students to express themselves in class. Students can express their own thoughts and contribute to the further improvement of the communicative competence.

Disadvantages. The communicative principle requires the teaching of the process of communication, which requires a very skilled grasp of the knowledge of the foreign language. It not only include the knowledge of the language, but also have the necessary knowledge, to understand the country's language habits, customs, and so on. But if the foreign language teaching itself does not have this kind of quality, then he cannot create a good communication environment for foreign language learners, learning the effect will be greatly reduced. Therefore, the communicative approach is more suitable for the primary stage of learning the foreign language, where there are full and real communicative conditions and good communication environment, and the things that have learned can be used in life.

\section{Applications of the Communicative Principle in Russian Teaching}

Applications in Dialogue Teaching. In Russian language teaching, dialogue is regarded as the main method to master Russian. It is an organization form of Russian teaching process and a kind of language activity in Russian language teaching. Dialogue as a speech activity has its own characteristics.It is a combination of speech activities within a certain framework and reproduction; the whole dialogue is composed of two dialogue; each dialogue participants take turns as the listener and speaker. The deduction method is to take a dialogue as an example, in order to the structure of the dialogue, intonation as the standard, let the students themselves to make a similar dialogue with it. The dialogue paradigm can be seen as a dialogue between several dialogue units, this method is generally from the students listen and understand the entire dialogue as a beginning, and then the students make clear on the basis of the elements of the dialogue, with other words to replace the practice, through a lot of practice to let students sum up the law, so as to create a dialogue with the example. The advantage of this method is that students can master the language structure naturally: from the overall tone of the sentence structure to their composition, from the whole to the part, students can more easily understand the dialogue. However, the disadvantage is not conducive to the development of students' ability to use material independently.

Applications in Grammar Teaching. Grammar is an important part of language. It mainly includes rules for word morphological changes and the use of language. Grammar is important, people in the process of communication, in accordance with the rules of a certain grammar to the choice of vocabulary, so that the meaning of the word into a coherent whole, used to express ideas, to achieve the purpose of communication. If a language does not have a system of grammar, then in the process of communication, language will be no logic. As we all know, there are two ways of grammar teaching: deduction and induction. Deduction method is to present the grammar rules to students, let them accept and understand the grammar rules, use this rule to identify the grammatical phenomenon, solve the problem of grammar, for communication. Inductive method is just the opposite.It is the first to show the phenomenon of grammar to students, so that students have such a question: why there will be such a phenomenon, so as to guide students to sum up the grammar rules. In the course of the Russian grammar teaching, the teachers should use the teaching materials to meet the needs of students to take part in all kinds of tests. And for different grammatical phenomena combined with deductive method and inductive method, in the teaching process of large-scale, repeated practice, to apply the learned grammar rules into meaningful words, enable students in communicative process can unthinkingly blurted out, and to achieve the communicative purpose. For example, explain the active form of the verb, the inductive method to explain the 
active form of the verb form. It can not only avoid the lengthy to explain the students lose interest in learning, but also can deepen students' impression.

Applications in Vocabulary Teaching. Vocabulary is the basic unit of a sentence. In the process of communication, people connect words and words according to certain grammatical rules and language habits as a tool of communication. It is well known that Russian is a morphological changes in the abundance of language, this and our native language Chinese is have very different, which in the process enable us to learn Russian met some difficulties. At the same time, due to the lack of a certain Russian environment, we have to use the vocabulary in the classroom, in addition to the use of foreign exchange in the classroom, in the classroom cannot use the time to use, the learning of knowledge cannot be consolidated, which led to the students will be part of the single word forgetting, which in a certain extent, the students to learn Russian initiative and confidence. Therefore, vocabulary teaching plays an extremely important role in Russian teaching. In the course of teaching, teachers should use various teaching methods to make students better grasp the Russian vocabulary. For students who have just begun to learn Russian, we can use real objects, pictures, slides, and even facial expressions and gestures in the teaching process to stimulate students' perception of organs and help them to practice.

Applications in Text Teaching. Russian reading course is a course of analysis and reading Russian texts. From the lower grade to higher grade, it is to explain and read the text. Although the reading class is not much, but it occupies the time and the students spend most of the time, the teaching focus is to explain and read the text, so that students master pronunciation, grammar and vocabulary knowledge, training and enhance the sense of language. When you first listen to or read a text, you should first establish the subject of the article. What is the purpose of the author in writing the text the central idea of the article is to determine the style of the article determine the structure of the article the use of a number of people in the case of the time. When you listen to or read the article, you must determine the contents of each part of the content, that is, to understand the main content of each section; determine the main ideas of the development of logic; determine the structure of each part of the structure of a functional type. When the last time to listen to or read the text, pay special attention to and try to remember the beginning and end of the article as accurately as possible, pay attention to the various parts of the article is how to combine together, and finally determine the main content of the article and remember the key sentences in the article. For students of different grades, we can adopt different method to study the text: low grade students in the explanation of the text, first of all, the teacher read it again. Then ask the students to read aloud, then students staged reading, for more dialogue text can also role in reading, if there is a mistake in the process of reading, in reading the whole fragment by other students of error correction. In order to increase the interest, the students read the other students to specify the other students to carry on the translation, the translation of the wrong place can be corrected by the teacher or other students. After reading and translating the whole text, the students read the text again, let the students do not read books. The teacher puts forward some questions for students to answer the questions, and fully mobilize the enthusiasm of the students, so that they have more language practice in the classroom. And for the high grade students, teachers do not need to read firstly. Russian teachers can let the students to read the passage quickly, and then guide the students to use their own words toreport the text.

\section{Conclusion}

The purpose of learning a language is to communicate. The communicative principle is an important means to improve the communicative ability. It is necessary to focus on how to cultivate students' communicative competence. Therefore, in the teaching process, it is necessary to focus on how to cultivate students' communicative competence. Therefore, in the teaching process, the teaching process should be based on the students. In a harmonious and pleasant situation, teachers can realize the resonance of teaching and learning in the situation. Only in this way can we improve the quality of the teaching of Russian language. 


\section{References}

[1] L.J. Zhang, Russian Teaching and Communication Culture, Journal of Shenyang College of Education, 3(2002)61-63.

[2] Z.Z. Ye, The teaching of Russian Proverbs and Sayings in Cross-Cultural Communication, Journal of Nanchang College of Education, 8(2013)173-179.

[3] L.R. Song, The Russian Teaching under the Cultural Differences between China and Russia-To Discuss the Cross-cultural Communication and Personnel Training. Journal of Heihe University, 8(2011)66-68.

[4] N.N. Qu, The Application of Communicative Principles in College English Teaching, J. Xi'an Univ. of Arch. \& Tech. Social Science Edition, 5(2013)93-96. 